\title{
Transformation of labour rights: a solution to protecting prisoners in China?
}

\begin{abstract}
In China the system of reform through labour pesists in law and in practice, this paper will explore the possibility or necessity of transforming labour rights within the framework of international law and investigate whether such transformation produces any resolution to the rights conflict over the reform through labour programme in China.
\end{abstract}

Volume 7 Issue 2 - 2019

\author{
Na Jiang,' Yue Wang² \\ 'Professor, College for Criminal Law Science, Beijing Normal \\ University (BNU), China \\ ${ }^{2}$ LLM candidate, Beijing Normal University, China
}

\begin{abstract}
Correspondence: Na Jiang, Professor, College for Criminal Law Science, Beijing Normal University (BNU), China, Email na.jiang@bnu.edu.cn
\end{abstract}

Received: February 19, 2019 | Published: April 23, 2019

\section{Introduction}

According to the protected interests and normative environments within the above international labour standards, labour rights may be transformed on the basis of three primary aspects. These aspects include transformation in the subject of labour, in its requirements with respect to content and in its intended objects and purposes. Among these aspects, a transformation in intended objects and purposes may be the core solution to the rights conflict, given that China has not ratified all of its international human rights treaties and that prohibition of forced labour is uncertain to be an international customary norm. Thus, the transformation of labour rights could be developed thorough labour reforms involving the Constitution, criminal law and justice or labour rights in China to solve the rights conflict, of which those in the Constitution is at the core of such transformation as follows:

\section{The possibility of transforming labour rights}

States may intend to provide a higher law to govern all forms of activities protecting labour rights; the Constitution regulates the primary principles concerned. The Constitution of the PRC, adopted in 1982, has been amended four times: in 1988, 1993, 1999 and 2004. These amendments have contributed to China's economic, political, cultural and social development and progress, but they have retained the Constitutional right and duty to labour for three decades, leaving open the possibility of a justice system that includes forced labour. Article 42 of the 1982 Constitution stipulates that work is the right and "glorious duty of every able-bodied citizen." This provision means that every able-bodied citizen has the obligation to work, whether the citizen wishes to or not; moreover, it deviates from the provisions on the right to work found in the International Covenant on Civil and Political Rights (ICCPR) and International Covenant on Economic, Social and Cultural Rights (ICESCR). Pursuant to Article 8(3)(a) of the ICCPR, State parties are obliged not to compel their citizens to work by any positive measure, including legal measures. The right to work is optional and does not imply the duty to work; a duty to work suggests that work is compulsory in nature. Article 6(1) of the ICESCR also provides for a right to work, comprising the individual's claim or opportunity "to gain his living by work which he freely chooses or accepts". Hence, the general duty to work that could be imposed by States through penal sanction constitutes forced or compulsory labour and is therefore contrary to Article 8(3)(a) of the ICCPR and Article $6(1)$ of the ICESCR. Even though compulsory labour is inconsistent with international labour standards, the above constitutional clause was reasonable when China had a planned economy. Provisions for the duty to work contributed to good social order and income equality, thereby upholding the notion of egalitarian ideals and a stable living standard among citizens participating in the planned economy. As a result, the labour system was able to successfully overcome the disordered state that prevailed in China when it had a market economy and to establish a good social order. The State undertook the obligation to assign to every citizen some form of employment; thus, citizens enjoyed the equal right to employment and income equality. Without the risk of unemployment or bankruptcy, every citizen had stable work and enough income for a peaceful life. The belief that "an advantage of a socialistic society is that everyone has food and work" was generally accepted by the Chinese public.

\section{The necessity of transforming labour rights involving the constitution}

After the establishment of a market economy in the 1980s, however, the duty to labour has increasingly demonstrated a series of shortcomings that are inconsistent with contemporary life in China. The outdated idea of a duty to labour has led to a lack of understanding of the nature of work in a market economy, practical difficulties and inconsistencies among laws. Such negative influence will be addressed in detail as follows. First, in theory, a legal duty is compulsory, and a legal right is optional. If work is a right, citizens can choose at will whether to work. If work is a duty, citizens must fulfil their legal obligations or face punishment. Therefore, it does not make sense to refer to work as both a right and a duty. Moreover, neither the Constitution of China nor any other law provides for any sanctions against able-bodied citizens who refuse to participate in the labour market. As the 1999 Amendment to Article 6 of the 1982 Constitution states, the State adheres to "the distribution system with the distribution according to work remaining dominant and the 
coexistence of a variety of distribution means" during the current stage of socialism. In practice, with the establishment and development of a market economy, citizens have been able to earn income in numerous ways. Chinese citizens can gain personal economic income through saving account interest, stock dividends, annual bonuses from their employer and financial awards for achievements at work, rent and even inheritance to complement their basic wages. Second, the present situation precludes the notion of work as citizens' legal duty for two primary reasons.

At present, the size of the work force in China is so large that it is impossible to find work for every citizen at the same time. Under the circumstances of a market economy, a certain unemployment rate is retained to promote labour competition and to improve work efficiency. China's economy follows this rule. It is therefore impossible or impractical to ensure the employment of every citizen in contemporary China. Third, two points are worthy of note concerning conflicts between different Chinese laws. One point is that every citizen's duty to work is inconsistent with the retirement system enshrined in Article 44 of the 1982 Constitution. This system applies to retired "workers and staff in enterprises and undertakings" and "functionaries of organs of state" whose livelihood "is ensured by the state and society". Because retirement is compulsory once workers reach a certain age, many able-bodied citizens must leave work positions even though they remain "able bodies" and can still fulfil their duties. The system is designed to allow workers to peacefully rest in their later years, whereas the 1982 Constitution requires all able-bodied citizens to continue to work, implying that such citizens have no right to retire. The other point is that the duty of all citizens to work is often confused with the duty of criminals to work. As indicated in Articles 7(2) and 69 of the 1994 Prison Law, to participate in labour is the legal obligation of every able-bodied criminal and a means for the State to compel criminals to reform themselves through labour. This special duty of criminals to work is similar to and not clearly demarcated from provisions regarding the universal duty of citizens to work. Furthermore, for several reasons, it is unlikely that workforce participation will significantly decrease if the duty to work is eliminated from the 1982 Constitution. First, in most States, the Constitution emphasises the right of citizens to work without explicitly imposing the duty to work.

Many of these States do not have workforce participation rates that are significantly lower than China's. China should consider this fact when further reforming its legal provisions. Second, historically, there were express provisions mandating a duty to work in the 1954 Constitution and the 1975 Constitution, and it does not appear that Chinese people worked any less prior to 1982 . Third, work has become a practical necessity and even a lifestyle for most Chinese citizens. Specifically, work is the essential and primary means through which the majority of citizens obtain their livelihood, develop socially and enhance their social welfare. Since the abolition of the exploitation system in China, most Chinese citizens have had a negative attitude towards all forms of unearned income. Thus, most Chinese citizens are willing to do some form of work as the primary means of maintaining their own subsistence, development and welfare. Moreover, many citizens consider work to be interesting and structure their lifestyle around their job. These citizens would be unwilling to give up work because work contributes to their happiness. Fourth, Chinese morality includes the idea that citizens should work for both social development and to enhance the wealth of their nation. Chinese citizens understand the important correlation between the public interest of China and the personal interest of its citizens. This moral idea and strong awareness would encourage Chinese citizens to work, even if the 1982 Constitution abolished their duty to do so. Finally, the fact that some citizens obtain income outside of work tends not to cause any direct harm to the State, society or other citizens. Therefore, it is not necessary to resort to legal means to prohibit such income; rather, protecting such means of income to an extent may be desirable.

\section{Conclusion}

In brief, it is not necessary, reasonable or feasible to stipulate work as a legal obligation of Chinese citizens; thus, labour should not be considered a legal duty. The Constitutional basis of work should be revised so that only the right to work is protected, not the duty to work. This revision would not only correct inconsistencies in Chinese law but also bring China into compliance with the ICCPR and ICESCR.

\section{Acknowledgments}

None.

\section{Conflicts of interest}

The author declares that there are no conflicts of interest. 